\title{
Isolation of ATPase Accelerating Peptides from Fur Seal Muscle Hydrolysate*1
}

\author{
Toru TAmIYA ${ }^{* 2}$, Minoru YoshidA*2, Takahide TsuchiYA*2, \\ Masao TANAKA*2, Masataka KIKUNO*2, \\ and Juichiro J. MATSUMOTo*2 \\ (Received December 7, 1976)
}

\begin{abstract}
In the previous paper, the ATPase accelerating peptides were found to be distinct from the vasoactive and vasodilatory peptides in the same hydrolysate.

This work was undertaken to isolate the ATPase accelerating peptide from the fur seal muscle hydrolysate. Minced skeletal muscle of fur seal was digested with protease and the resulting hydrolysate was fractionated with $90 \%$ ethanol. The obtained precipitate and supernatant were examined for accelerating effect on carp actomyosin ATPase and the effective agent was found only in the precipitate. By continuous flow electrophoresis, the precipitate was divided into five major fractions, each of which was examined for accelerating effect on ATPase by two different methods, $i, e$, inorganic phosphate determination and $\mathrm{pH}$-stat method. Among the five electrophoretic fractions, the second fraction E2 migrating to the anode showed the best accelerating effect, while the other fractions were less accelerative. Also the possible effect of $\mathrm{Ca}$ ions was refuted. E2 was also examined for physiological activity by kymographic recording of the contraction of rat intestine smooth muscle and showed an effect which is revealed by a contraction preceded by a slight relaxation. Thin layer chromatography revealed that there are more than two peptide components in fraction E2.
\end{abstract}

The presence of new vasoactive and vasodilatory peptides in the hydrolysate of fur seal skeletal muscle has been reported by HAYASHI et al. ${ }^{11}$, as well as HAYASHI and SUZUKI ${ }^{2}$, and the peripheral vasodilating action, $i$. e. stimulation of blood flow, of the peptides has been proposed by MATSUKawa et $a .^{3)}$ and Suzuki et al ${ }^{4)}$.

The presence of ATPase activity and superprecipitation accelerating peptides in the same hydrolysate of fur seal muscle has been reported by MATSUMOTO et al. ${ }^{5}$, and TAMIYA et al. $^{\left({ }^{2}\right)}$ revealed that the accelerating effect of peptides on ATPase activity and superprecipitation is related with but distinct from the vasoactive and vasodilatory peptides.

With the aim to clarify the nature and functional mechanism of the above accelerating and preventive effect on the contractile activity of muscle, the authors took up the isolation of the ATPase accelerating peptide from the hydrolysate of fur seal skeletal muscle.

\section{Materials and Methods}

Fur seal muscle Skeletal muscle of fur seal, Callorhinus ursinus, caught in the waters off Hokkaido, were obtained through the courtesy of the Fur Seal Research Section of

*1 Studies on biochemical activity of fur seal muscle hydrolysate peptides-III. Presented at the Annual Meeting of Japanese Society of the Scientific Fisheries at Tokyo, April 3rd, 1972.

*2 Department of Chemistry, Sophia University, Kioi-cho 7, Chiyoda-ku, Tokyo 102. (田窝 徹 ・占田 稳・土屋隆英・田中正男・菊野正隆・枟本重一郎). 
Far Sea's Fisheries Research Laboratory, Fisheries Agency. The muscles were frozen at $-20^{\circ} \mathrm{C}$ until use.

Preparation of peptides Preparation of the peptide fractions of fur seal muscle hydro. lysate was carried out by the method described previously ${ }^{6}$. After extraction with $60 \%$ ethanol, the ethanol was removed by vacuum evaporation and the resultant ethanol-free solution was used for the further fractionation.

Carp actomyosin The method described previously ${ }^{53}$ was applied for preparation using live dorsal lateral muscle of carp, Cyprinus carpio.

Continuous flow electrophoresis Continuous flow preparative electrophoretic apparatus model "VAP" (Bender Hobein Co. Ltd.) was used. Conditions were as follows: Buffer of separating chamber, $0.05 \mathrm{M}$ triethylamine-acetic acid $(\mathrm{pH} \mathrm{6.1)}$; electrode buffer, $0.25 \mathrm{M}$ triethylamine-acetic acid $(\mathrm{pH} 6.1)$; sample concentration $10 \%(w / v)$; velocity of the sample, $3 \mathrm{ml} / \mathrm{hr}$; D. C. voltage, $1700 \mathrm{~V}$; current, $145 \mathrm{~mA}$ (constant); temperature, $4^{\circ} \mathrm{C}$.

ATPase activity Enzymatic measurments were carried out under two different methods as follows: 1) Activity was measured by determining the liberated inorganic phosphate by FISKE-SUBBARow's method after stopping the enzymatic reaction with trichloroacetic acid. Conditions of the enzymatic reaction were as follows: carp actomyosin, $0.2 \mathrm{mg} / \mathrm{ml} ; \mathrm{KCl}, 50 \mathrm{~mm}$; tris-maleate buffer, $20 \mathrm{mM}(\mathrm{pH} 7.0)$; ATP, $1.0 \mathrm{~mm}$; peptide, $1.0 \mathrm{mg} / \mathrm{m} l$; temperature, $25^{\circ} \mathrm{C}$. 2) Activity was measured by the $\mathrm{pH}$-stat method, the liberated $\mathrm{H}^{+}$ions being determined with a Type TTTlc titrator, Radiometer Copenhagen, after adding ATP solution. Sodium hydroxide solution, $4.33 \times 10^{-4} \mathrm{~N}$ was introduced into the reaction mixture through a thin polyethylene tube and was immediately mixed in with a magnetic stirrer. A constant current of nitrogen gas was passed over the surface of the reaction mixture. Conditions and components of the reaction mixture were as follows: actomyosin, $0.2 \mathrm{mg} / \mathrm{ml}$; ATP, $0.2 \mathrm{mM} ; \mathrm{CaCl}_{2}, 2 \mathrm{mM}$; peptide, $0.4 \mathrm{mg} / \mathrm{ml}$; temperature, $25^{\circ} \mathrm{C} ; \mathrm{pH} 8.2$.

Physiological activity Male albino rats of an inbred Wister strain, 150-170 g weight were used in this experiment. Ileum was cut off accompanying the connected stomach and preserved in Tyrode's solution* for ten minutes. Then the $2-3 \mathrm{~cm}$ long ileum adjacent to the stomach was cut off and washed with Tyrode's solution and set in the kymograph. The peptide and other solutions were put in the Tyrode's bath in which the muscle was suspended.

Thin layer chromatography Silica gel (Wakogel B-5, Wako Junyaku Co. Ltd.) $0.5 \mathrm{~mm}$ thick, $20 \times 20 \mathrm{~cm}^{2}$; developing solvent, $\mathrm{PrOH}+\mathrm{H}_{2} \mathrm{O}(7: 3)$; nihydrin reaction were employed for localization of spots.

\footnotetext{
* $\mathrm{NaCl} 8 \mathrm{~g}, \mathrm{CaCl}_{2} 0.2 \mathrm{~g}, \mathrm{KCl} 0.2 \mathrm{~g}, \mathrm{NaHCO}_{8} 1.0 \mathrm{~g}, \mathrm{MgCl}_{2} 0.1 \mathrm{~g}, \mathrm{NaH}_{2} \mathrm{PO}_{4} 0.05 \mathrm{~g}$ were dissolved in $100 \mathrm{~m} /$ of water.
} 
Unless otherwise stated, other preparative and analytical methods used were the same as those described in the previous papers ${ }^{5,6}$.

\section{Results and Discussion}

Fractionation with ethanol When ethanol was added to the ethanol free solution to bring the concentration up to $90 \%(v / v)$, some precipitate was formed. This was filtered, washed with ethanol followed by acetone and vacuum dried to give a pale yellow powder, the (ethanol-) precipitate $P_{1}$, while the filtrate was concentrated and lyophilized to give the (ethanol-) supernatant, $S_{1}$.

Both the precipitate $P_{1}$ and the supernatant $S_{1}$ were subjected to examination for the accelerating effect on ATPase activity of carp actomyosin. When the precipitate $P_{1}$ was added to the reaction mixture prior to adding ATP, the ATPase activity of carp actomyosin was slightly accelerated as compared with the control, while the supernatant $S_{1}$ inhibited the ATPase activity (Fig. 1). This indicated that the ATPase activity accelerating component must be in the precipitate $P_{1}$, while some ATPase inhibiting components exist in the supernatant $S_{1}$.

The relationship between concentration and absorbance given by the biuret reaction
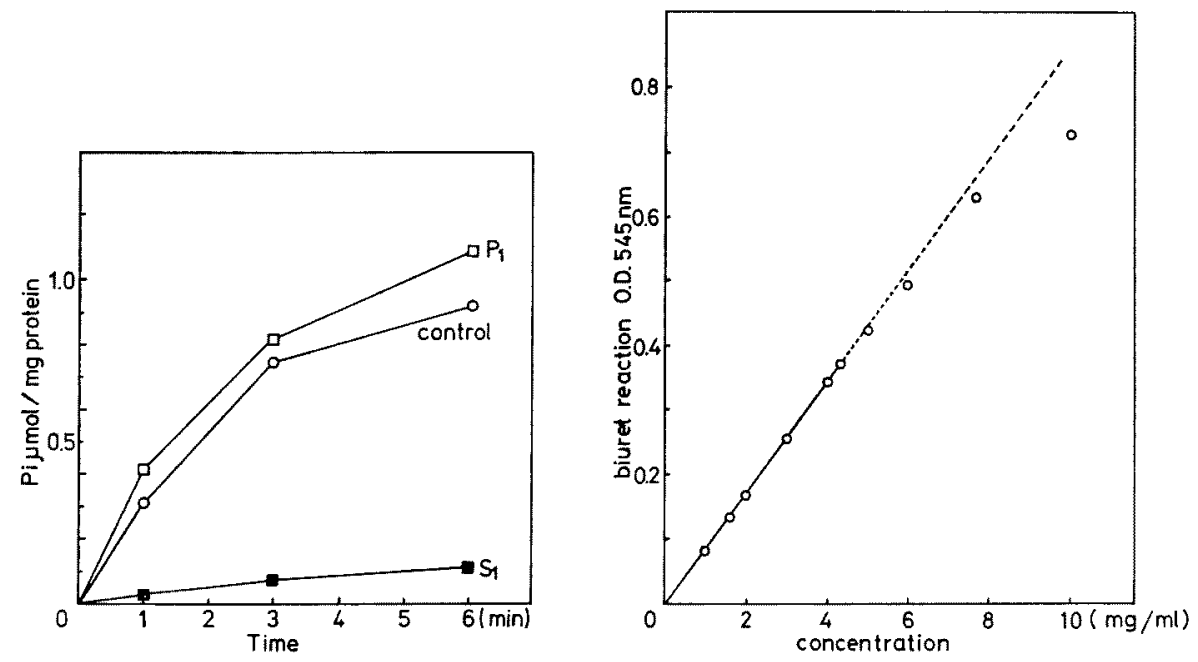

Fig. 1. Effect of (ethanol-) precipitate $P_{1}$ and (ethanol-) supernatant $S_{1}$ on ATPase activity of carp actomyosin.

Conditions: carp actomyosin, $0.2 \mathrm{mg} / \mathrm{m} l ; \mathrm{KCl}, 50 \mathrm{~mm}$; tris-maleate buffer, $20 \mathrm{~mm}(\mathrm{pH}$ 7.0); ATP, $1 \mathrm{~mm} ; \mathrm{S}_{1}$ and $\mathrm{P}_{1}, 1.0 \mathrm{mg} / \mathrm{ml}$; temperature, $25^{\circ} \mathrm{C}$.

Fig. 2. Relationship between violet coloration of biuret reaction and concentration of (ethanol-) precipitate $P_{1}$.

Absorption (per $1 \mathrm{~cm}$ depth) of biuret reaction was measured by Hitachi 124 spectrophotometer. 
of precipitate $P_{1}$ is shown in Fig. 2, from which the following equations have been formulated:

$$
C=A_{545 \mathrm{~nm}}^{1 \mathrm{~cm}} \times 1.16, \quad a^{*}=0.862
$$

where $C$ is the peptide concentration $(\mathrm{g} / \mathrm{d} l), A$ is the absorbance, the equation being effective below absorbance value 0.43 and $a^{*}$ is absorption coefficient.

Electrophoretic fractionation Further fractionation of the precipitate $P_{1}$ was tried by the continuous flow electrophoresis. About $70 \mathrm{ml}$ of the sample solution was applied into the separating chamber and separated into 48 fractions. Figure 3 shows the result of a typical run in which the distribution of the absorbance of direct ultraviolet measurement (at $270 \mathrm{~nm}$ ), biuret reaction (at $545 \mathrm{~nm}$ ) and ninhydrin reaction (at $570 \mathrm{~nm}$ ) indicates the presence of five major fractions (E1-E5).

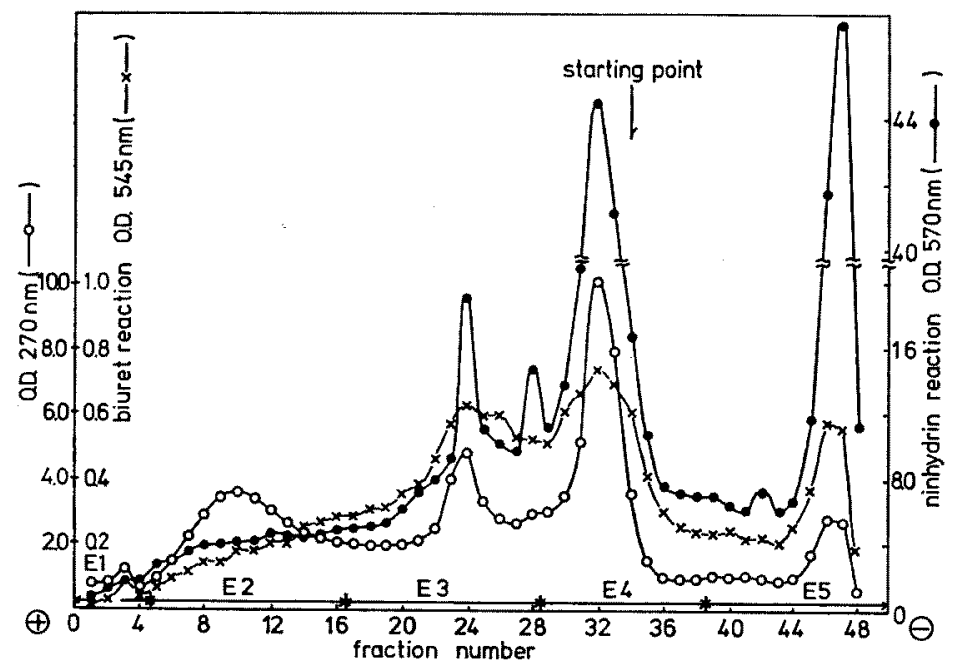

Fig. 3. Fractionation of precipitate $P_{1}$ by continuous flow electrophoresis.

Conditions: buffer of separating chamber, $0.05 \mathrm{M}$ triethyamine-acetic acid (pH 6.1); electrode buffer, $0.25 \mathrm{M}$ triethylamine-acetic acid (pH 6.1); sample concentration, $10 \%$ $(w / v)$; velocity of the sample, $3 \mathrm{ml} / \mathrm{hr} ; \mathrm{D}$. C. voltage, $1700 \mathrm{~V}$; current, $145 \mathrm{~mA}$ (constant); temperature, $4^{\circ} \mathrm{C}$.

The difference of ratios between the different analytical methods shows that the peptide composition of each fraction is different one another.

The accelerating effect of these five fractions on carp actomyosin ATPase was examined after evaporating the buffer solution off and adjusting the $\mathrm{pH}$ to 7.0 with $\mathrm{NaOH}$. In each enzymatic reaction mixture, the peptide concentration was made up to $1 \mathrm{mg} / \mathrm{m} l$ by means of a preliminary biuret determination. As shown in Fig. 4, E2 showed the strongest accelerating effect among the five major fractions on ATPase activity as determined by FISKE-SUBBAROW's method. Its ATP splitting rate was 1.5-fold that of the control.

* referred to as $\mathrm{E}$ in the previous paper ${ }^{6)}$. 
Figure 5 shows a similar study on the effect of E2 by the pH-stat method. In this case, the lyophilized powder of E2 was used, its final concentration being adjusted to 0.4 $\mathrm{mg} / \mathrm{ml}$. In this experiment, the effect of E2 with and without $\mathrm{Ca}$ ions on ATPase activity was examined. The ATP splitting rate with added E2 was about two times faster than the control. The presence of $\mathrm{Ca}$ ions itself raised the rate to about four-fold the control, but the presence of both E2 and Ca ions accelerated the ATPase activity still more.

Although the accelerating effect was suspected to be due to contaminant $\mathrm{Ca}$ ions in the peptide preparation as discussed in the previous paper, this was disproved by the present results, because $\mathrm{E} 2$ was the fraction migrating towards the anode. Therefore, the accelerating effect on the actomyosin ATPase must be that of the added peptides themselves. The question whether this specific effect of these peptides is due to an allo-

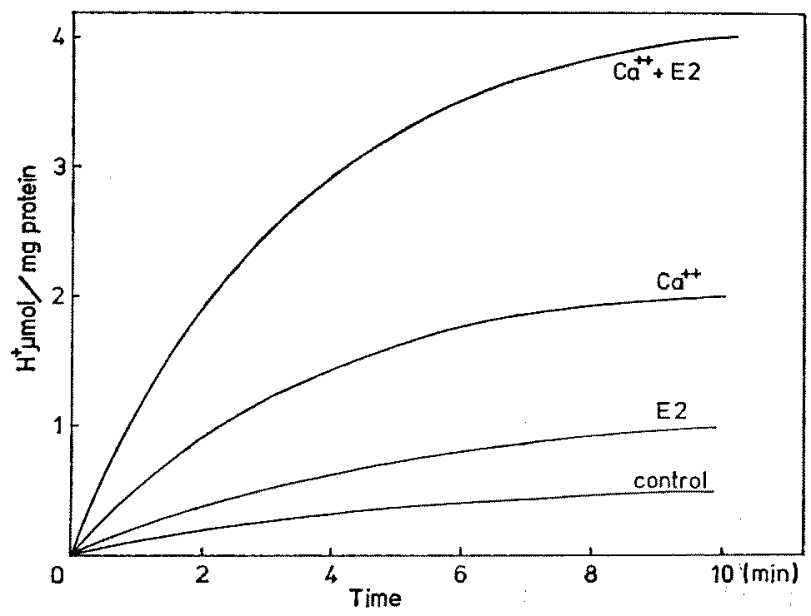

Fig. 5. Effect of electrophoretic fraction E2 on ATPase activity of carp actomyosin as determined by $\mathrm{pH}$-stat method.

Conditions: carp actomyosin, $0.2 \mathrm{mg} / \mathrm{ml} ; \mathrm{ATP}, 0.2 \mathrm{~mm} ; \mathrm{CaCl}_{2}, 2 \mathrm{mM} ; \mathrm{KCl}, 400 \mathrm{~mm} ; \mathrm{E} 2$, $0.4 \mathrm{mg} / \mathrm{ml} ; \mathrm{NaOH}, 4.33 \times 10^{-4} \mathrm{~N} ; \mathrm{pH} 8,2$; temperature, $25^{\circ} \mathrm{C}$.

The splitting rate of ATP is expressed as the volume of $\mathrm{NaOH}$ solution added to keep the pH to 8.2.

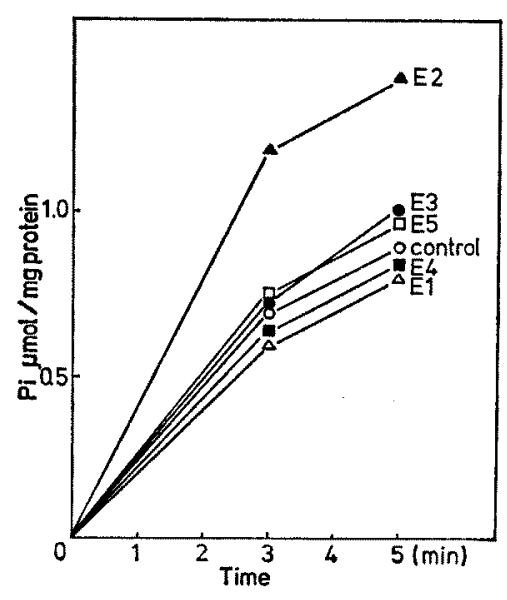

Fig. 4. Effect of electrophoretic fractions (E1-E5) on ATPase activity of carp actomyosin as determined by FISKESubBarow's method.

Conditions: carp actomyosin, $0.2 \mathrm{mg} /$ $\mathrm{ml}$; ATP, $1 \mathrm{~mm}$; $\mathrm{KCl}, 50 \mathrm{~mm}$; trismaleate buffer, $20 \mathrm{mM}(\mathrm{pH} \mathrm{7.0)}$; E1-E5, $1.0 \mathrm{mg} / \mathrm{ml}$; temperature, $25^{\circ} \mathrm{C}$. 


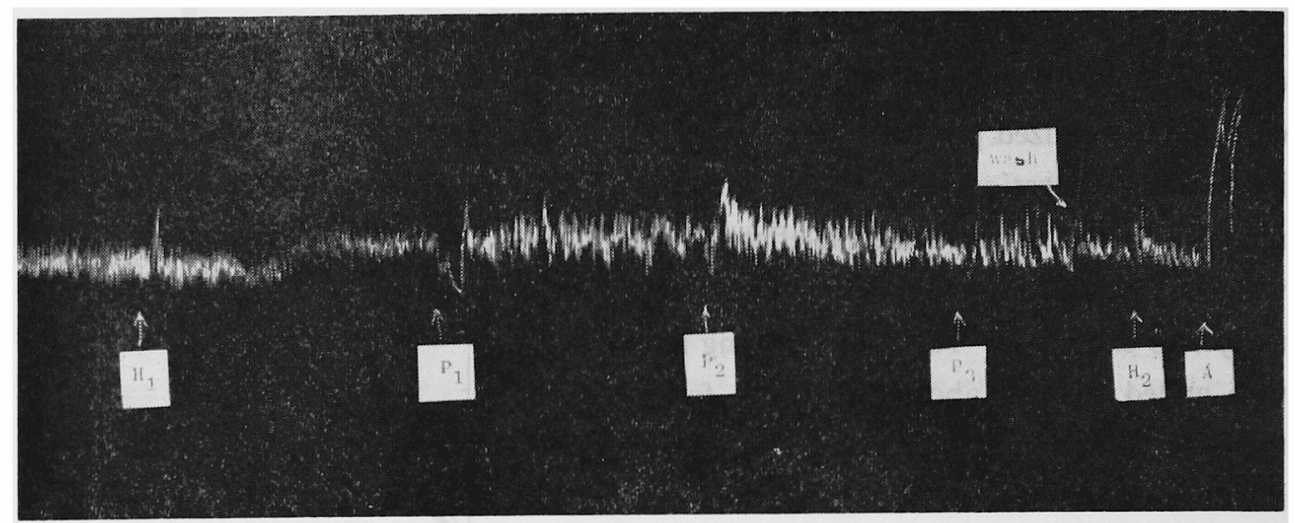

Fig. 6. Kymograph of contraction of rat intestine smooth muscle on added electrophoretic fraction E2, acethylcholine or histamine.

$\mathrm{H}_{1}$ : histamine, $2 \times 10^{-3} \mathrm{mg} / \mathrm{ml}$

$\mathrm{H}_{2}$ : histamine, $4 \times 10^{-3} \mathrm{mg} / \mathrm{ml}$

$\mathrm{P}_{1}$ : peptide fraction $\mathrm{E} 2,0.1 \mathrm{mg} / \mathrm{m} l$

$\mathrm{P}_{2}$ : peptide fraction $\mathrm{E} 2,0.01 \mathrm{mg} / \mathrm{m} l$

$\mathrm{P}_{3}$ : peptide fraction $\mathrm{E} 2,0.3 \mathrm{mg} / \mathrm{m} l$

A: acethylcholine, $0.01 \mathrm{mg} / \mathrm{m} l$

steric or other kind of mechanism is left for further study.

The electrophoretic fraction E2 was also examined for the contractile activity on smooth muscle of rat ileum by kymograph. As shown in Fig. 6, when E2 was added to the medium Tyrode's solution to give a final concentration, $0.1 \mathrm{mg} / \mathrm{m} l$ or $0.3 \mathrm{mg} / \mathrm{ml}$, an appreciable contraction occured after a slight relaxation. The same piece of muscle showed a strong contraction with acetylcholine, $1 \times 10^{-2} \mathrm{mg} / \mathrm{ml}$, and slight one with histamine, $2 \times 10^{-3} \mathrm{mg} / \mathrm{ml}$ and $4 \times 10^{-3} \mathrm{mg} / \mathrm{ml}$, but no relaxation was found in these cases. Thus, E2 showed not only ATPase accelerating activity but also inducing a contraction of smooth muscle. Though the working mechanism of the effect of the peptide is unknown, it is likely that the effect is brought about through the modification of actin-myosin contractile

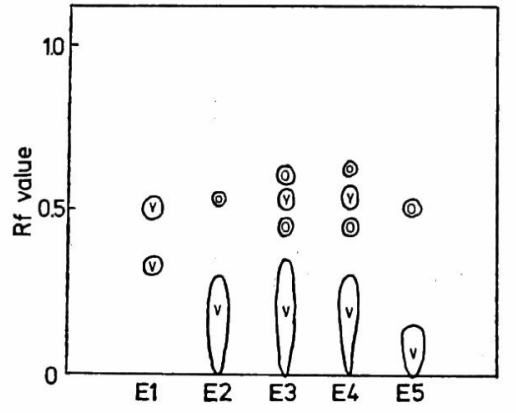

Fig. 7. Thin layer chromatography of electrophoretic fractions.

$\mathrm{Y}$ : yellow $\mathrm{O}$ : orange $\mathrm{V}$ : violet system itself.

Further analysis of the electrophoretic fractions was done by thin layer chromatography (Fig. 7). While the other four major fractions from continuous electrophoresis showed two to four ninhydrin reactive spots, E2 showed two spots, the one with the lower $R f$ value being very broad, still indicative of its heterogenious composition. These results suggest that the ATPase accelerating E2 obtained from continuous electrophoresis 
contains several peptides which must involve acidic amino acids since they migrated toward the anode. Further fractionation of E2 will be discussed in succeeding papers.

\section{Ackowledgement}

The authors are indebted to the members of the Fur Seal Research Section, Far Sea's Fisheries Research Laboratory for providing the fur seal materials.

\section{References}

1) T. Hayashi, T. Otsuka, S. Aikawa, and H. Hoshino: Keio J. Med, 15, 227-243 (1966).

2) T. HaYashi and T. Suzuki: This Bull., 33, 1044-1049 (1967).

3) H. Matsukawa, H. Ito, and T. Suzuki: ibid., 40, 1139-1143 (1974).

4) T. Suzuki, H. Matsukawa, and H. Ito: ibid., 40, 1195-1179 (1974).

5) J. J. Matsumoto, T. Suzuki, Y. Asaka, N. Tamaki, S. Utsugi, H. Minaguchi, and T. Tamiya: ibid., 42, 1033-1040 (1976).

6) T. Tamiya, H. Minaguchi, S. Utsugi, T. Suzuki, and J. J. Matsumoto: ibid., 42, 1299-1304 (1976). 